\title{
A Comparison of the Image of Home in Mongolian Horqin Lyric Folk Songs and American Cowboy Songs
}

\author{
Shuanglian $\mathrm{Chen}^{1}$ \\ ${ }^{1}$ School of Foreign Languages, Inner Mongolia University for the Nationalities, China \\ Correspondence: Shuanglian Chen, Tongliao, School of Foreign Languages, Inner Mongolia University for the \\ Nationalities, Tongliao City, Inner Mongolia, China. Tel: 86-139-4758-2115. E-mail: chenshuanglian@163.com
}

Received: September 26, 2013 Accepted: October 10, 2013 Online Published: November 24, 2013

doi:10.5539/ells.v3n4p46 URL: http://dx.doi.org/10.5539/ells.v3n4p46

\begin{abstract}
Folk songs are the valuable cultural storehouse of a people or an ethnic group, because the original life styles, thoughts, view of marriage and love of a people all find their expressions in folk songs. Folk songs have been trying to tell the rise and decline of its cultures and its peoples in their own ways. They began to come into being almost from the time when the people or the ethnic group formed. Home is an eternal topic in most folk songs. Homesick songs make up a premier category of Horqin folk songs. The image of home is also indispensable in American cowboy songs. This paper tries to build a bridge between two seemingly distant cultures by comparing the image of home in Mongolian Horqin lyric folk songs with that in American western cowboy songs. Both of these folk songs are trying to present the real stories of authentic people as their topics even if some rhetorical devices are employed sometimes in order to show more vivid characters. Characters in both songs are lonely. The spiritual and physical loneliness of the characters in both songs is so much alike. But the dissimilarities are more obvious. The different historical and cultural backgrounds and the distinct geographical and social environment of two folk songs are the best explanation to these dissimilarities.
\end{abstract}

Keywords: Mongolian Horqin folk songs, American cowboy songs, spiritual home, physical home, comparative study

\section{Introduction}

Folk songs are traditional songs of a people or an ethnic group. They are passed down usually orally from one generation to another, from one group of people to another. With no very clear authorized writers for most songs, folk songs tend directly to express the simple emotions of people. This artistic form tends to carry the memories of the whole group. Folk songs show special cultural features because they take shape in a special historical environment. Most folk songs may take shape in the process of labor while the singers try to relieve themselves of the labor. Some songs are invented to get rid of loneliness. The others are designed to kill the time when the singers are doing long and tedious labor. People's ways of life, common value, customs, traditions, thoughts all find their expressions in folk songs. Home is an indispensible topic for most folk songs. Surely there is not an exception to both Mongolian Horqin lyric folk songs and American cowboy songs.

\subsection{Horqin Folk Songs}

Mongol is an ethnic group that settles in the far northern province of China called Inner Mongolia Autonomous Region. They are located just beyond the Great Wall of China. The Mongols living in the eastern part of Inner Mongolia is called Horqin Mongols, who are the direct descendents of Kasar, a brother of Genghis Khan. Because of the special landscape for herding and the distinct political environment in the eastern Mongolian steppe, the Horqin Mongols have developed a very fascinating music form called Horqin folk music. Horqin folk songs began to take shape from the thirteenth century, but the most of the songs people sing and study today formed only in recent a hundred years. There are many categories in Horqin folk music: short lyric folk songs, long narrative songs, Shaman music, ulgur songs, holboos, mangus ulgur and Andai Dance. Among them the short lyric folk songs are the most popular one. These songs enjoy a distant origin, a long history of development and a great variety. Having the feature of exposing some social issues with true stories of authentic people and with a strong local color, these folk songs have already been valued as national intangible cultural heritage of China in 2008. The variety in singing styles such as narrative singing, antiphonal singing, solo singing all makes them more attractive. These songs are usually accompanied by Mongolian musical instruments as matouqin (a 
horse-head musical instrument with four strings), huur (a four-stringed musical instrument) and choor (a two-stringed musical instrument). Furthermore, these folk songs cover vast topics from love, loneliness, banquet, horses and battles to home. Besides, the songs of praise and the long narrative songs in Horqin folk songs are unique among many other folk songs.

\subsection{American Western Folk Songs}

American folk music is a musical term that encompasses numerous genres, many of which are known as traditional music, traditional folk music, contemporary folk music or roots music. American western music was originally composed by and about the people who settled and worked throughout the Western United States and Western Canada. These folk songs are directly related musically to old English, Scottish and Irish folk ballads. Among all these genres, one branch called cowboy songs contributes greatly to the development of western music as a local-born music. These cowboy songs usually "celebrate the life of the cowboy on the open ranges and prairies of Western North America" (Western Music, 2013). The early cowboy songs were supplemented sometimes with string bands as banjo and guitar occasionally with the harmonica. The historic American cowboy of the late 19th century arose from the vaquero traditions of northern Mexico and became a figure of special significance and legend (Cowboy, 2013). With the need of great expending westward of the United States, many young people were involved in the great tide of moving west and became the westward pioneers. The cowboy songs not only range from the topic of work, trails, law, life to death, but most importantly deal with the subjects of love, heroic deeds, tragic fate and homesick feelings etc. Especially those songs about home add to the beauty and grandeur of the west. And those songs about home have become the most popular and most influential part.

"Home still rocks my soul, steals my dreams each night." Holy Tashian expresses his love towards home in his words. Home is the place where your beloved are. And wherever you go and whatever hardships you meet in life, you should always turn to your home for protection, help, ease and everything.

Home is the label which indicates one's origin. The one who is deprived of home is like the maverick on the cattle land. So every time when one feels frustrated and disappointed, one can turn to his home as sanctuary. Songs of home, in fact, make up a premier category of both Horqin lyric folk songs and American cowboy songs. Do they resemble each other when they express homesick feelings? What are the similarities if they do resemble each other? Are there any differences between the two homesick songs? What are their differences? And what are the reasons for these similarities and differences? It is obvious that both songs express the longing for the spiritual home and the physical home. But the reasons for their longings are different. This makes a comparative study on the image of home in Horqin lyric folk songs and American cowboy songs possible. And the significance of this comparative study is worth considering.

\section{Longing for Spiritual Home}

Home on the spiritual level is always far more emphasized in most folk songs. In those songs, what people miss and care is not the place itself but the people who are there and the warmness and protection that home gives them.

\subsection{Longing for Spiritual Home in Horqin Lyric Folk Songs}

Many Horqin lyric folk songs tend to express homesick feelings of women who have married far away from home. Mongolian people used to have the habit of marrying daughters to people in distant villages. It is said that in the clan society the Mongolian people developed the tradition of distant marriage in order to keep the pure lineage or bloodline. Maybe in the later days, this tradition was also coupled with some other factors. Some noble families tried to enlarge their power and strengthen their ties with another force. But the ordinary folk married their daughters to people from distant villages usually on the basis of economic advantage. They liked to marry girls to men from wealthy families even if they lived far away from their hometowns. Whatever reasons may there be, the girls' desire and emotions were never considered for their own marriages. So the sad lives of many girls began. That is the way many homesick songs of Horqin Mongols came into being. In the sparsely populated vast territory of Inner Mongolia, the transportation used to be so difficult. As soon as the girls married far away, it became extremely difficult for the brides to see their families and hometowns again. They had no relatives, no friends on these strange lands, so after everyday's labor and the abusive treatment from their new families, what they did was only to stand by the doorway to look in the direction of their homes and sing these self-pity homesick songs. They sang those homesick songs and struggled in the misery. The melody of these songs is usually pathetic which makes the singers sob and the listeners touched. Among these homesick songs, the typical ones are "Nuunjiya", "Axima" and "Yun Liang".

Nuunjiya was a beautiful girl who was born in a well-off family and grew up happily in her hometown on 
Horqin Naiman grassland, a banner or a county in eastern part of Inner Mongolia. When she grew to a beautiful girl, her father, according to the distant marriage tradition, married her to a guy in a far-away village who was the son of a royal highness in Uzhumqin Banner of Xilingol League. Thus began Nuunjiya's miserable life. As it is sung in the song:

There is a horse with a bridle,

on the bank of Haiqin River.

The lovely and cheerful girl Nuunjiya, married into a place far away.

Here they do not cultivate the farm land, so they do not eat melons.

What a delicious taste of mum's breast milk, when I suck it continuously!

Here Nuunjiya compares herself to the horse with a bridle on the bank of the river. She leaves her hometown and could not integrate herself into the new surroundings. She becomes a maverick as a horse who has lost its owner. In another Horqin folk song "Axima", the far-married girl Axima sings:

My father who falls victim to the liquor,

married me, his daughter, into a place one thousand kilometers away.

I do not blame him for selling me so far away,

but I hate the match-maker Lama in the Hiyagtu Temple.

It has been ten years since they married me so far away,

and I have not even received a piece of bread from them.

What I am missing is not the bread itself,

but I want to know whether my parents are still in good health (Unonbaoyin, 2007).

Axima, the singer of this song misses terribly her parents and hometown. Many of those women get older gradually and some of them do not even have a single chance to see their homes in their lifetime. That is a terrible tragedy for most girls and also to their families. There are also many songs singing for mum and dad in other songs called songs of relatives. Those songs include "Oh, Mother", "The Love of Mum", "Father's Instruction" and so on. In "Xira Hada", one sings:

On the top of the Brown Cliff,

there is a deep layer of snow.

As soon as I think of my mum,

I have watering eyes (Unonbaoyin, 2007).

The singers of these songs sing them mainly to relieve themselves of their homesick feelings, but usually the more they sing, the more they feel homesick. And the quiet, slow and sentimental melody of these songs also adds to the tragic beauty of the songs.

\subsection{Longing for Spiritual Home in American Cowboy Songs}

Home is always the "authentic center of American life, and that center necessarily stirs yearnings that occupy a tremendously powerful place in the imagination." (Tichi, 1994). Home is usually free from hatred, envy, false beliefs and other negative affections. American cowboy songs express homesick feelings of cowboys. The cowboys experience hardships and torture in the cattle business. They feel lonely and disillusioned because of the hard life. They dream of wide open spaces, freedom in life and rich opportunities in the west. But the reality shatters their dreams and cripples their hopes. The weeks of trails, the long hours in the saddle riding on the prairie alone always make them weary and tired. Some cowboys even begin to question their original decisions of leaving their hometown and the beloved to this strange land. The dull and routine work makes them feel bored, as it is shown in the song "The Dreary, Dreary Life" or "Cowboy's Life Is A Dreary, Dreary Life":

The cowboy's life is a dreary, dreary life,

he's driven through the heat and the cold.

When the rich man's sleeping on his velvet couch,

Dreaming of his silver and gold (Silber, 1967).

The dreary life makes cowboys hope to "stay at home", and they suggest to the others who have followed their suit "all cowpunchers take my advice: Sell your bridle and saddle, quit your roving and travel, Tie on to a pretty 
little wife." The stable home is a real attraction for cowboys. Home also means the mother. When the ranger in "The Texas Rangers" thinks of his approaching death, he thinks yearningly of his mum and what she says, "My time has come to die... I thought of my dear mother, in tears to me say, 'To you they are all strangers, with me you'd better stay." Maybe the thought of Mum could bring him the courage to fight in the battle and also the courage to face the death.

In "Red River Valley" the singer expresses a very complicated feeling towards the Red River. He loves it since it saves him too many good memories. By singing:

Come and sit by my side if you love me.

Do not hasten to bid me adieu.

But remember the Red River valley,

And the cowboy that loves you so true (Tinsley, 1981).

He is comparing the river to the girl he loves. He hates to part from the beloved girl. The other songs "Western Home", "Home on the Range" all express people's longings and yearnings for home.

It seems that the reason for cowboy singing is more obvious than the other folk songs. Cowboy songs occurred in quantity after the Civil War. "During that period two things had awakened the world to the dangers and picturesqueness of his career" (Monaghan, 1963). The great profit of the cattle industry and the picturesqueness of cowboy skills attract so many young people to go west. The hectic air of the young soldiers who just return from the battlefields could find nowhere to give off than to find a new game. The pursuing for their life value and personal dream together with their adventurous spirit helps push them west. Surely they have made great contribution to the nation's history. And they themselves have benefited a lot in their process of opening the old west. But they have also paid the price for their recklessness. Most things are just out of their expectations.

Price is even fatal to some. The strenuous environment always threatens their lives. Hostile Indians are always ready to steal their horses and cattle. Rattlesnakes and coyotes threaten their lives. Raging rivers and dog holes always set barriers for their trail and herding. Stampeding would be destructive not only to the cattle but also to the cowboys themselves. Drought, hailstorm, blizzard, snows, rains, lightening and thunder always torment those riders. Most importantly those riders are only teenagers who are just out of high school or from the battlefields. The harsh life of night herding and the long time cut off from civilization almost break their hearts.

"Home" in those songs does not mean the mere physical place, but also something that is buried in heart. The cowboys miss their original home maybe because they have never had the home of true value on this vast territory.

\section{Longing for Physical Home}

Home means not only the families who stay back in that place where one is born. It also means the nature, the surroundings in which one grows up. It is made up of mountains, rivers, sunlight, flowers, springs, cliffs, grasslands and even the deserts on which one plays happily with his playmates. So the songs in which the singer misses her or his mountains and rivers can also be called homesick songs. Both Horqin folk songs and American cowboy songs deal with these topics.

\subsection{Longing for Physical Home in Horqin Lyric Folk Songs}

"Long for a new place when one grows up. Miss the birthplace when one gets older." (Bao, 2009).This topic is usually obvious in Horqin lyric folk songs. When "his teeth fell out and his hair got grey", the elderly singer expressed his longing for home in his Horqin folk song "Wuljiimuren Gol". He sings:

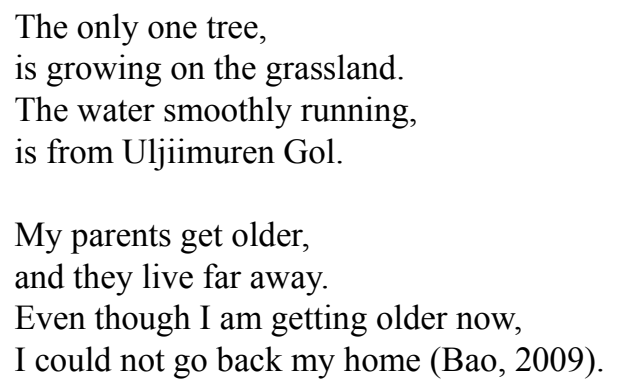

Here "Gol" means river and the lonely old man compares himself to the only tree standing lonely on the grassland. He curses his luck for not being able to return to his homeland to see his elderly parents.

In the song "Yun Liang", the far- married girl Yun Liang sings: 
I once sat in the sedan chair carried by eight men, and I visited the eight streets and eighty lanes there.

Even if the eight streets and eighty lanes are beautiful, they are not comparable to Lagli Village where I was born (Bao, 2009).

The famous hero song, "Bingtu Wang" tells the story of a Mongolian hero called Bingtu Wang. "Bingtu Wang" means the chief of Bingtu Banner (County). He fights against Yuan Shih-kai, the warlord in order to establish a self-governed Mongolian county. But he failed and sacrificed his life in the battle. In the song, he is singing:

I have inherited the military rank from my fathers, and I have the title of Wang in my local government.

Because I insist on fighting against the bastard trouble-maker, Yuan Shih-kai, I can't go back to my hometown Bingtu Banner any more.

The Red Clean River is running in the front, and my elderly grandmother who loves me so much is there.

My dear hometown Bingtu Banner, it's very difficult for me to be back to you (Unonbaoyin, 2007).

These songs have already rooted in the minds of millions of Horqin Mongols. They love the nature and the surroundings in their hometowns as if they love their parents and siblings.

\subsection{Longing for Physical Home in American Cowboy Songs}

American western cowboy songs also follow that tradition. The cowboys usually describe their hometown as something "dearest", "sweet" and "lovely". Not only those leaving behind strike their memories but also the moonlight, forests, mountains and rivers hook their souls. As it is sung in "Home on the Range":

O give me a home where the buffalo roam,

Where the deer and the antelope play.

Where seldom is heard a discouraging word,

And the skies are not cloudy all day (Lingenfelter, Dwyer, \& Cohen, 1968).

As these haunting, comforting strains from "Home on the Range" miraculously came out of the air, the whole nation somehow felt that it still had some good things among the crashes and depressions of the age (Tichi, 1994). The song not only brought people the good memories but also cheered them up. In "The Hills of Mexico" the cowboy sings:

And now the drive is over,

And homeland we are bound,

No more in this damned old country, Will ever I be found.

Back to friends and loved ones,

And tell them not to go,

To the God-forsaken country,

They call New Mexico (Tinsley, 1981).

He expresses his intense passion for home with a plain language. In the song "Back to Arizona", a cowboy who went east was hit by a bad spell of homesickness and sang this chorus:

I am going back to Arizona,

That's where I want to be.

I've got a gal in Arizona,

I'd like mighty well to see.

I've got a cow in Arizona,

With a calf I'd like to brand,

I've got a hoss in Arizona,

Running with a mustang band.

I'm going back to Arizona,

And round them up some day,

And whoop and yell in the big corral,

Come a ti yippy yippy yea. 
The image of home in these songs is so powerful. The desire of going back home is so strong that one just can not wait any longer. So the cowboy "started back to my once loved home".

So no matter they sing, "O bury me not on the lone prairie, Where the coyotes howl and the wind blows free" or "O bury me out on the prairie, Where the coyotes may howl o'er my grave.", the singers hope to express one theme. That is they love their home forever no matter it is their original home or it is a new one.

In both songs, home displays a very fascinating picture in people's minds. The thought of home and the friends around the cheerful fireside with no apprehensions of danger from enemies or suffering from cold, hunger, rain and snow brings them a good memories and cheerful feelings.

\section{Conclusion}

Both the Horqin folk songs and the western cowboy songs resemble each other in their contents. Horqin girls and cowboys are missing both their physical home and spiritual home. By the physical home, it means they long for the place where they were born and had been brought up. They miss the mountains they climbed and the water they drank and swam as kids. All these memories torture them. They are spiritually lonely. Fathers, mothers, sisters and playmates always haunt their dreams. The lovers they left behind make them grieve. They could not find an authentic home in the wild west or in far-away villages. So the cowboys begin to question their original impulsive decision. In the same way, the Horqin Mongols consider their birthplace as their only home. The Horqin girls stand hopelessly by the doorway, looking toward their hometowns with watering eyes.

What is hidden behind the Horqin homesick songs is the indignation and helplessness of those characters against the arranged marriage tradition in feudal society. They begin to realize the unfairness of that marriage system and social tradition. This indicates the changes in people's minds and signifies the widespread of the New Cultural Enlightenment on the Mongolian grassland. The old tradition and an era are going to pass away.

Americans have modeled the icons of cowboys with courage, boldness and adventurousness to meet their own needs of image for American dream. The cowboy symbolizes a special period in American history. What cowboys have back home is the civilization from which the wild west is segregated. In other sense, the people in the wild west are looking forward to the peaceful, safe and better life as it is in the eastern civilized world, since the life there is "as peaceful as a baby's sigh". Even when they die, they hope to be buried in the churchyard beside their fathers. So in a sense, even the churchyard represents the civilized world. Yes, the wild west needs civilization.

But between homesick feelings for both songs an authentic difference exists. In Horqin folk songs, the characters show their helplessness towards the natural hinder and social barrier which keep them from their homes. They just could not reach their dream home because of some outside forces. These forces are from both nature and men. In "Nuunjiya" and "Axima", the girls could not see their parents and friends because there are not any transportation vehicles available for them on the Mongolian grassland at the time. The Bingtu Wang could not be back to his birthplace because of a more complicated political reason. It's true that the cowboys also could not go back home because the railways are not paved yet at the beginning of ranch lives. But it seems they could more easily reach their home by riding their horses and in later years riding on the trains of Union and Central Pacific.

However both the Horqin homesick songs and American cowboy homesick songs stand for a period in history. The characters in both songs symbolize an era for their peoples. These songs occur just because of that existing society. They show peoples' longing for a beautiful homeland and peaceful life.

Before this paper some scholars around the world have already conducted some research on the history and customs of Mongolian people and the American wild west respectively. But their theories usually focus on the rise and decline of the Yuan dynasty and the deeds of Ginghis Khan. Some other articles in the western academic circles also present a discussion over the cowboy culture. In China, many experts and scholars have also discussed the Horqin folk songs individually. But, a comparative study on these two songs is a new endeavor. In fact, Horqin Mongols in the eastern part of Inner Mongolia is quite unknown to the people in the world. Hence, this comparative study may help to introduce and promote the Horqin culture to the western world. Meanwhile it may open a new field for discussion.

\section{Acknowledgements}

I sincerely declare: this paper is my independent work. This paper does not include any published or written works of an individual or a collective except those which have already been given clear indication of reference.

Here I express my gratitude to the College at Brockport, State University of New York and China Scholarship Council who have offered me a chance to conduct a research in America. I also thank my home university who 
has supported me for all my teaching career.

My thanks will especially go to Dr. Jack R. Rollwagen, a knowledgeable anthropologist and professor at the College at Brockport, State University of New York and his wife Louise Stein, a warmhearted expert both of whom have given me a generous help during my research in America. Besides I also feel grateful to those people who have been trying to pass on such beautiful folk songs to the next generation.

I fully realize the legal result of this statement and I am ready to take any responsibility caused because of this paper.

\section{References}

Autry, G. (1978). Back in the Saddle Again. Garden City, NY: Doubleday of Company, Inc. New York.

Bakken, G. M. (2008). Icons of the American West: from cowgirls to Silicon Valley (Vol. 1). Westport, Conn.: Greenwood Press.

Bao, S. (2009). A Study of Horqin Folk Songs. Tongliao: Inner Mongolia Children's Publishing House.

Botkin, B. A. (Ed.). (1994). A Treasury of American Folklore, stories, ballads, and traditions of the people. New York: Crown Publishers.

Cowboy. (2013, January 8). In Wikipedia, the free encyclopedia. Retrieved January 8, 2013, from http://en.wikipedia.org/wiki/Cowboy

Horan, J. D. (1959). The Great American West: A pictorial History From Coronado To The Last Frontier. New York: Crown Publishers, Inc.

Lingenfelter, R. E., Dwyer, R. A., \& Cohen, D. (1968). Songs of the American West. Berkeley: University of California Press.

Lomax, J. A., Lomax, A., \& Waters, E. N. (1938). Cowboy Songs and Other Frontier Ballads. New York: The Macmillan company.

Monaghan, J. (Ed.). (1963). The Book of the American West. New York: Julian Messner Inc.

Rollwagen, J. R. (2011). China Odyssey—Song of the Grasslands: Ethnicity, Identity, Economic Development, Culture Change and Music among the Horqin Mongols of Eastern Inner Mongolia, China [DVD series]. Brockport, NY: The Institute, Inc. Retrieved from http://www.the-institute-ny.com

Silber, I. (Ed., \& Comp.). (1967). Songs of the Great American West. New York: The Macmillan Company.

Tichi, C. (1994). High Lonesome: The American Culture of Country Music. Chapel Hill: The University of North Carolina Press.

Tinsley, J. B. (1981). He Was Singing This Song: A collection of 48 traditional songs of the American cowboys with words, music pictures and songs. Orlando: University Press of Florida.

Unonbaoyin. (Ed.). (2007). Mongolian Folk Songs (1st vol., \& 2nd vol.). Tongliao: Inner Mongolia Children's Publishing House.

Western Music (North America). (2013, January 3). In Wikipedia, the free encyclopedia. Retrieved January 3 , 2012, from http://en.wikipedia.org/wiki/Western_music_(North_America)

White, J. I. (1975). Git Along, Little Dogies: Songs and Song Makers of the American West. Urbana: University of Illinois Press.

\section{Copyrights}

Copyright for this article is retained by the author(s), with first publication rights granted to the journal.

This is an open-access article distributed under the terms and conditions of the Creative Commons Attribution license (http://creativecommons.org/licenses/by/3.0/). 